\title{
Makna Seni Ukiran Gorga Pada Rumah Adat Batak
}

\author{
Karolina Sianipar, Gugun Gunardi, Widyonugrahanto, Sri Rustiyanti \\ Universitas Padjadjaran (UNPAD) Bandung \\ Jalan Raya Jatinangor KM. 21 Sumedang 45363
}

\begin{abstract}
This paper entitled "The meaning of art carving on custom home gorga Batak". Gorga carving is a form of art carvings typical of indigenous Batak culture. This paper aims to determine the various forms of carving on custom home gorga Batak. Gorga carving shape manifold, so that on any form of carving gorga have different meanings. Therefore, this paper also aims to understand the meanings that exist in gorga carving. Within the meaning of carving gorga using semiotics approach. Semiotics is to approach the study of signs. In the traditional house of Batak carving gorga meaning of life, which it is drawn through the forms on each carving.
\end{abstract}

Keywords: Carving, Gorga, Traditional House of Batak

\begin{abstract}
ABSTRAK
Tulisan ini berjudul "Makna seni ukiran gorga pada rumah adat batak". Ukiran gorga merupakan salah satu bentuk kesenian ukiran khas kebudayaan adat batak. Tulisan ini bertujuan untuk mengetahui berbagai bentuk dari ukiran gorga pada rumah adat batak. Bentuk ukiran gorga bermacam-macam, sehingga pada setiap bentuk ukiran gorga memiliki makna yang berbeda-beda. Oleh karena itu, tulisan ini juga bertujuan untuk memahami makna yang ada pada ukiran gorga. Dalam pemaknaan ukiran gorga menggunakan pendekatan semiotika. Semiotika ialah pendekatan ilmu yang mempelajari tentang tanda. Pada ukiran gorga rumah adat batak memiliki makna kehidupan, yang mana hal ini tergambar melalui bentuk-bentuk pada setiap ukiran.
\end{abstract}

Kata kunci : Ukiran, Gorga, Rumah Adat Batak

\section{PENDAHULUAN}

Indonesia memiliki berbagai macam kebudayaan yang sangat luas. Salah satu kebudayaan yang ada di Indonesia ialah seni kebudayaan ukiran gorga. Gorga merupakan ukiran yang menjadi sebuah ciri khas dalam kebudayaan batak. Biasanya gorga terdapat pada bagian luar eksterior rumah Batak, sehingga baik masyarakat Batak ataupun wisatawan dapat memandangi bentuk ukiran gorga ${ }^{1}$. Pada bangunan-bangunan tradisionil tempat tinggal adat batak memiliki istilah yang disebut jabu Batak. Jabu merupakan istilah yang berarti rumah, sedangkan jabu ruma merupakan rumah adat. Rumah adat batak dibagi menjadi dua, yaitu: jabu ruma yaitu rumah adat tanpa gorga dan jabu ruma gorga artinya rumah adat pakai gorga (Sitanggang, 2008: 151). Ukiran gorga pada 
jabu batak memberikan kesan estetika yang tinggi dan memberikan makna-makna filosofi yang menarik untuk diamati lebih lanjut.

Ukiran Gorga memiliki ciri khas tersendiri terutama dalam bentuk lekukan ukirannya. Bagi masyarakat Batak ukiran sendiri memiliki nilai-nilai simbolis dan magis. Ukiran tradisional lahir dan berkembang seiring dengan peradaban masyarakat. Pada masyarakat tradisional batak kental dengan unsur-unsur magis. Oleh karena itu, beberapa masyarakat batak masih menanggap bahwa dalam ukiran gorga terdapat unsur magis didalamnya (diakses melalui http://www.anneahira.com/tanggal 16 Juni 2014,jam 15.48).

Pada penggunaan hiasan ukiran gorga, pemakaian ornamen tidak dapat dipakai sembarangan. Masyarakat Batak harus melakukan musyawarah untuk menentukan jenis gorga yang pantas dipakai menurut kedudukan pada satu kampung itu. Keindahan akan ukiran gorga pada ruma jabu batak membuat munculnya pertanyaan bagaimana jenis bentuk ukiran gorga di rumah tradisional adat batak. Berbagai jenis bentuk ukiran gorga memberikan arti satu sama lain.

\section{METODE}

Ukiran gorga memiliki makna filosofi, sehingga untuk mengetahui hal tersebut dibutuhkan teori semiotika. Semiotika merupakan sebuah teori yang mempelajari tentang sebuah tanda. Dalam hal ini penulis akan menggunakan teori semiotika dari Ferdinand de Saussure. Tanda ialah sebuah konsep yang sangat mendasar. Tanda adalah segala sesuatu yang memiliki makna relasi antara sesuatu yang abstrak dan sesuatu yang konkrit. Ferdinand de Saussure, dalam Berger (2010: 14) menyatakan Tanda terdiri dari dua konsep yaitu penanda dan petanda, dan keduanya tidak dapat dipisahkan. Penanda dan petanda membentuk tanda. Teori semiotika digunakan untuk mengetahui makna melalui relasi tanda-tanda yang ada dalam sebuah ukiran gorga.

Melalui teori semiotika, maka kita akan melihat makna apa yang terkandung dalam sebuah ukiran gorga. Pemahaman mengenai makna ukiran gorga menarik untuk diketahui. Ukiran gorga menjadi ciri khas sebagai bentuk seni budaya adat batak yang saat ini masih ada.

\section{PEMBAHASAN}

Ukiran gorga merupakan kesenian ukiran yang biasanya terdapat pada setiap bagian luar eksterior rumah Batak. Ukiran gorga memiliki nilai estetika yang tinggi karena memiliki makna didalamnya. Pada ukiran gorga terdapat bentuk-bentuk yang bermacam-macam. Gorga diklasifikasi dalam berbagai jenis yang berkaitan dengan bentuk. Adapun jenis-jenisnya ialah gorga sompi, gorga ipon-ipon, gorga desa na ualu (mata angin), gorga simataniari (matahari), gorga simarogung-ogung, gorga singa-singa, gorga jenggar dan jorngom, gorga boras pati (cecak), gorga adop-adop (susu), gorga gaja dompak, gorga dalihan na toru, gorga simeol-eol, gorga sitagang, gorga sijonggi, gorga silintong, gorga iran-iran, gorga hariara sudung di langit, gorga hoda-hoda, dan gorga ulu paung.

Berbagai macam bentuk ukiran gorga, sehingga jenis ukiran gorga memiliki makna yang berbeda-beda. Dalam hal ini dibutuhkan pisau bedah untuk mengetahui makna tersebut. Semiotika adalah ilmu yang mempelajari tentang tanda. Semiotika adalah cabang ilmu yang berurusan dengan peengkajian tanda dan segala sesuatu yang berhubungan dengan tanda, seperti sistem 
tanda dan proses berlaku bagi penggunaan tanda (Semiotika Aart van Zoest, dalam Soekowati, 1993: 1).

Sistem tanda ialah kombinasi antara sintagm dan paradigm, yang mana menggabungkan tanda dengan tujuan tertentu. Sintagm merupakan serangkaian tanda yang tersusun sesuai aturan untuk menghasilkan makna tertentu. Oleh karena itu, ketika seseorang mengatakan ukiran gorga, terdapat sebuah elemen-elemen tanda yang membentuk ukiran gorga tersebut, yaitu warna, bentuk, nama dan lainnya. Sedangkan paradigm ialah seperangkat elemen tanda yang satu dan lainnya dipertukarkan dalam konteks tertentu. Misalnya elemen warna pada gorga ada merah, hitam, putih. Oleh karena itu, sistem paradigm ialah seperangakat tanda yang memiliki pilihan-pilihan yang sama dalam konteks tertentu.

Menurut Roland Barthes, dalam semiotika terdapat makna denotasi dan makna konotasi yang memberikan arti penting. Makna denotasi bersifat langsung, dan dapat disebut sebagai gambaran dari suatu petanda (Berger, 2010: 65). Sedangkan makna konotatif ialah makna yang dihubungkan dengan kebudayaan yang tersirat dalam pembungkusnya, tentang makna yang terkandung didalamnya (Berger, 2000: 55). Makna denotasi dalam warna gorga misalnya, gorga memiliki tiga jenis warna yang dihiasi oleh cat, yaitu merah (narara), putih (nabontar), dan hitam (nabirong). Sedangakan makna konotasi pada warna gorga tersebut ialah warna merah (narara) sebagai ilmu pengetahuan dan kecerdasan yang berbuah kebijaksanaan. Kemudian warna putih (nabontar) bermakna ketulusan dan kejujuran yang berbuah kesucian. Terakhir warna hitam (nabirong) yang berarti kerajaan dan kewibawaan yang berbuah kepemimpinan.

\section{Bentuk dan Makna Ukiran Gorga}

Ukiran gorga memiliki makna yang berbeda pada setiap bentuknya. Menurut Sitanggang (2008) bahwa ada beberapa jenis ukiran gorga, yaitu:

\section{Gorga Sompi}

Gorga sompi berasal dari kata Tompi, artinya alat yang digunakan untuk mengikat leher kerbau pada gagang bajak sewaktu membajak di sawah. Gorga sompi dimaknai sebagai lambang ikatan kebudayaan. Pada masyarakat Batak Toba yang hidupnya selalu bekerja bergotong royong terjalin sebuah ikatan kekeluargaan. Oleh karena itu untuk melakukan suatu pekerjaan, tidak baik mengabaikan golongan lemah. Golongan lemah tidak boleh dipandang rendah. Fungsi dari ukiran ini dianggap sebagai peringatan bahwa tidak baik menyisihkan golongan-golongan tertentu dalam masyarakat supaya terdapat kehidupan sosial yang saling mencintai (Sitanggang, 2008: 146).

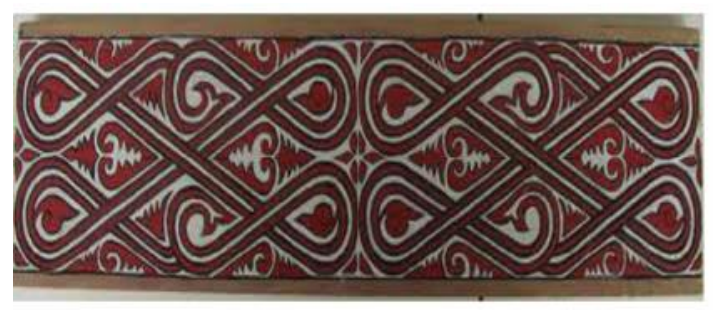

Gambar 1. Ukiran Gorga Sompi Sumber : http://akubatak.blogspot.com/ (diakses 18 Juni 2014)

\section{Gorga ipon-ipon}

Gorga Ipon-ipon merupakan gorga yang disebut sebagai hiasa tepi, berfungsi sebagai keindahan yang memperkuat komposisi. Beberapa gorga Ipon-ipon memiliki bentuk yang sama yaitu geometris, dan salah satu bentuk geometrisnya berlapis menyerupai empun, sehingga disebut 


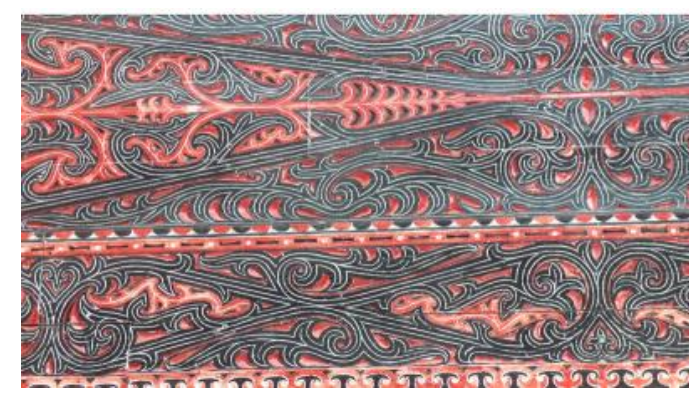

Gambar 2. Ukiran Gorga Ipon-ipon Sumber: http://hutagalunharean16. blogspot.com/ (diakses 18 Juni 2014)

sebagai Ombu Marhehe (diakses melalui www.gobatak.com tanggal 12 Juni 2014, jam 19.42 WIB) Ombu Marhehe dimaknai sebagai lambang kemajuan, karena setiap insan mengharapkan keturunannya berpendidikan (Sitanggang, 2008: 149).

\section{Gorga Desa na Ualu (Mata angin)}

Gorga Desa na Ualu merupakan ukiran gorga yang terdapat pada kanan kiri rumah adat Batak. Gorga Desa na Ualu sebagai simbol perbintangan yang menentukan saat-saat baik untuk manusia dalam melakukan aktivitas kerjanya seperti bertani, menangkap ikan, atau bahkan aktivitas ritual-ritual (Sitanggang, 2008: 154).

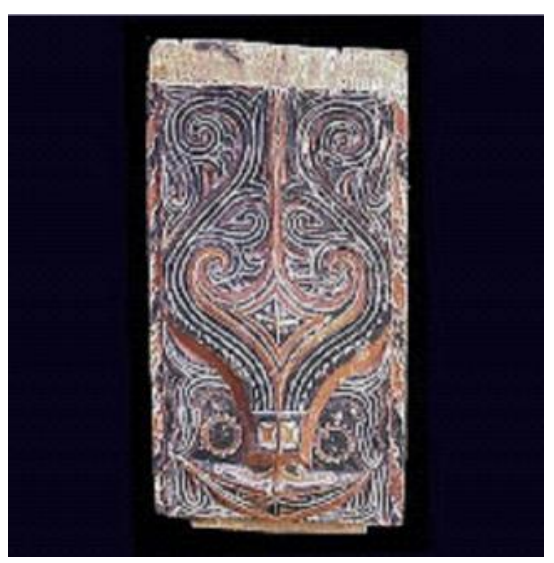

Gambar 3. Ukiran Gorga Desa na Ualu (Mata Angin), Sumber: http://2.bp.blog spot.com/gorga.jpg (diakses 18 Juni 2014)

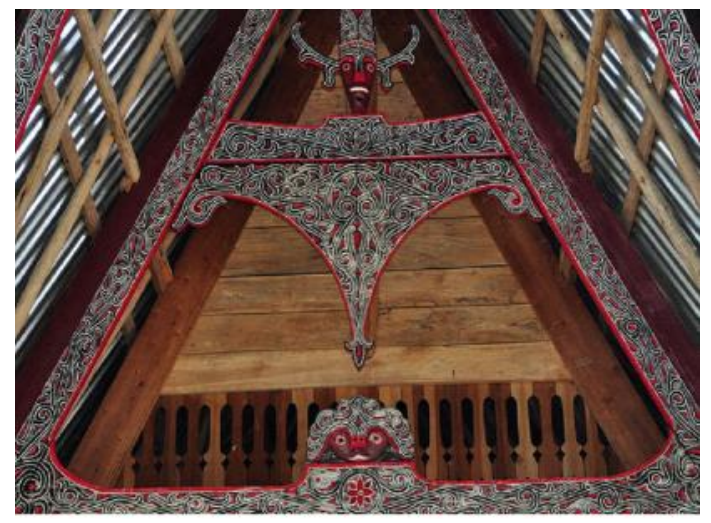

Gambar 4. Ukiran Gorga Simata ni ari (Matahari), Sumber : http://raymond sitorus.files.wordpress.com/, (diakses 18 Juni 2014)

\section{Gorga Simata ni ari (Matahari)}

Gorga Simata ni ari umunya diletakkan disebelah sudut dorpi. Mataniari bermakna sebagai sumber kekuatan hidup dan sebagai penentu jalan kehidupan. Oleh karena itu, Gorga Simata ni ari sering disebut purba manusia (Sitanggang, 2008: 154).

\section{Gorga Simarogung-ogung}

Ogung berarti alat musik Gong. Ukiran gorga simarogung-ogung terdapat disetiap rumah adat. Ukiran ini dimaknai sebagai kegembiraan. Gong dianggap sebagai simbol pesta yang diharapkan oleh masyarakat. Ukiran ini juga melambangkan kejayaan dan kemakmuran. Bagi orang yang yang memiliki kekayaan maka akan disebut parbahul-bahul na bolo, artinya

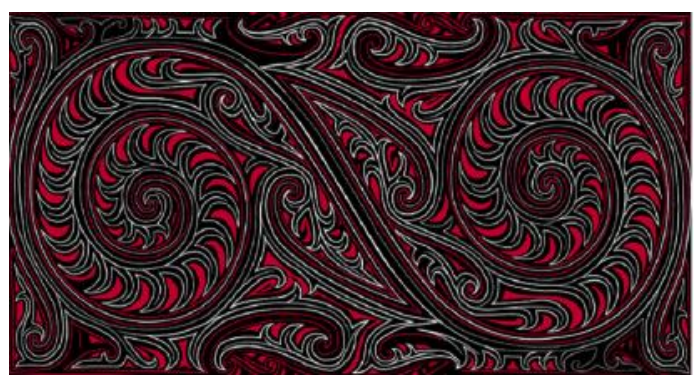

Gambar 5. Ukiran Gorga Simarogungogung, Sumber: www.photobucket. com/, (diakses 18 Juni 2014) 
seorang yang kaya yang penuh pengasih dan pemurah (diakses melalui www.gobatak.com tanggal 12 Juni 2014, jam 19.42 WIB).

\section{Gorga Singa-singa}

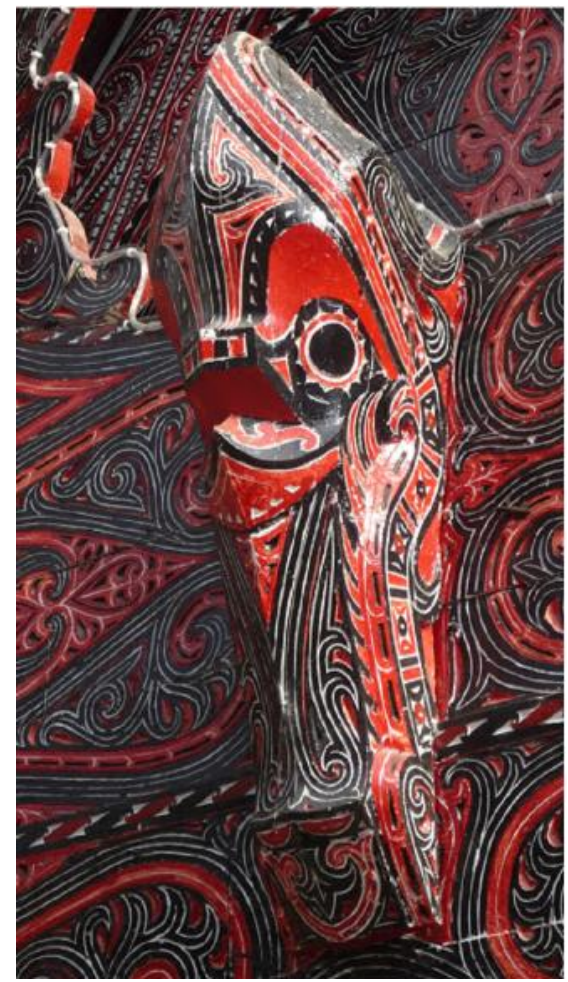

Gambar 6. Ukiran Gorga Singa-singa Sumber: http://erictogagultom.

blogspot.com/, (diakses 18 Juni 2014)

Gorga singa-singa berasal dari kata singa-singa, yang diartikan sebagai berkharisma dan berwibawa. Gorga singa-singa terdiri dari wajah manusia dengan lidah yang terjulur ke luar hampir mencapai dagu. Kemudian kepala dihiasi dengan kain tiga bolit dan sikap kaki yang berlutut persis di bawah kepala tersebut (diakses melalui www.gobatak.com, tanggal 12 Juni 2014, jam 19.42 WIB).

\section{Gorga Jenggar dan jorngom}

Gorga Jenggar dan jorngom merupakan gorga yang berbentuk raksaksa yang biasa

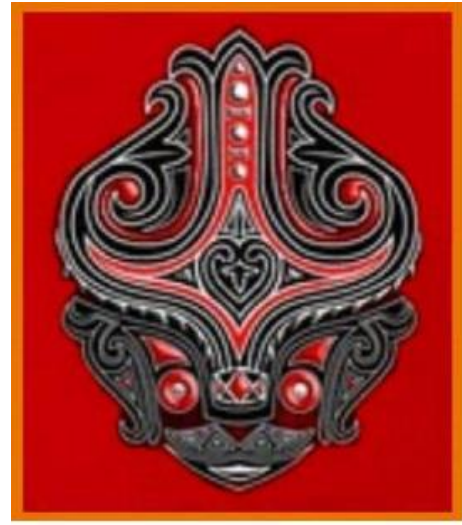

Gambar 7. Ukiran Gorga Jenggar dan Jorngom, Sumber: http:// batakone.files.wordpress.com/, (diakses 18 Juni 2014)

terdapat pada bagian tengah tomboman adop-adop dan halang gordang. Gorga ini mirip seperti hiasan yang terdapat di candi. Gorga Jenggar dan jorngom dimaknai sebagai penjaga keamanan. Bentuk raksasa dianggap sebagai dewa yang sanggup melawan segala jenis setan. Oleh karenanya, Gorga Jenggar dan jorngom dijadikan sebagai menjaga pintu untuk melawan segala jenis setan (Sitanggang, 2008: 154-155).

\section{Gorga Boras pati (Cecak)}

Gorga Boras pati (Cecak) disebut juga sebagai bujonggir yang berarti gambar cicak yang ekornya bercabang dua. Cicak ter-

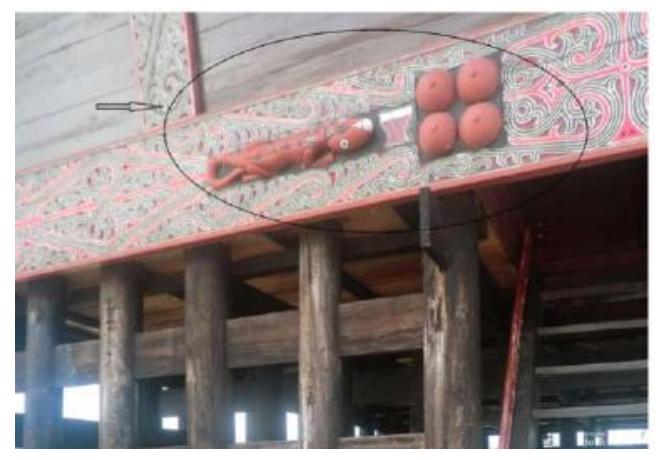

Gambar 8. Gorga Boras Pati (Cecak) Sumber: http://travel.detik.com/ (diakses 18 Juni 2014) 
sebut terkadang memberikan peringatan sebuah tanda-tanda melalui tingkah laku dan suaranya yang bisa membantu manusia terhindar dari bahaya ataupun mendapatkan kekayaan. Oleh karenanya gorga ini memiliki makna yang menyimbolkan akan pelindung harta kekayaan manusia dan mengharapkan dapat berlipat ganda (diakses melalui www.gobatak.com, tanggal 12 Juni 2014, jam 19.42 WIB).

\section{Gorga Adop-adop (Susu)}

Gorga Adop-adop (Susu) berbentuk hiasan susu yang selalu dihiasi oleh boraspati sehingga seolah mulutnya mendekati susu. Gorga Adop-adop (Susu) bermakna sebagai susu atau payudara yang melambangkan kesuburan dan kekayaan. Sering dibuat sebagai lambang keibuan (inanta parsonduk bolon) artinya pengasih dan penyayang (diakses melalui www.gobatak. com, tanggal 12 Juni 2014, jam 19.42 WIB).

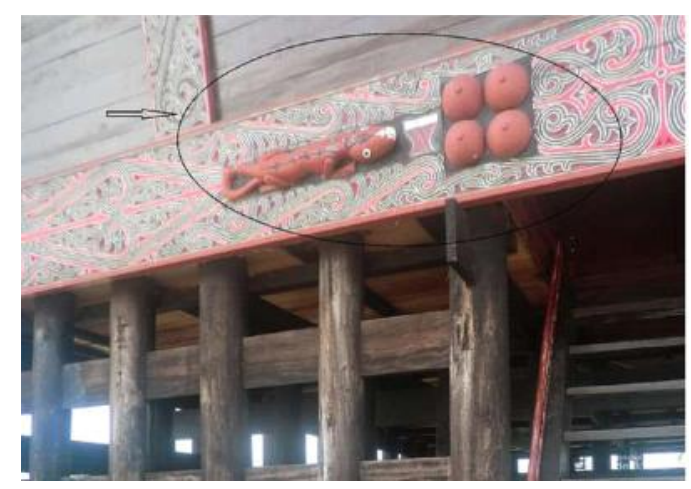

Gambar 9. Gorga Adop-adop (Susu) Sumber: http://travel.detik.com/ (diakses 18 Juni 2014)

\section{Gorga Hariara Sudung di Langit}

Gorga Hariara Sudung di Langit memiliki bentuk seperti pohon hayat yang dimiliki seperti suku Sumatera Selatan atau gunungan suku Jawa. Gambar burung sebelah atas disebut manuak-manuak hulambujati, dan warna putih membawa berkah.

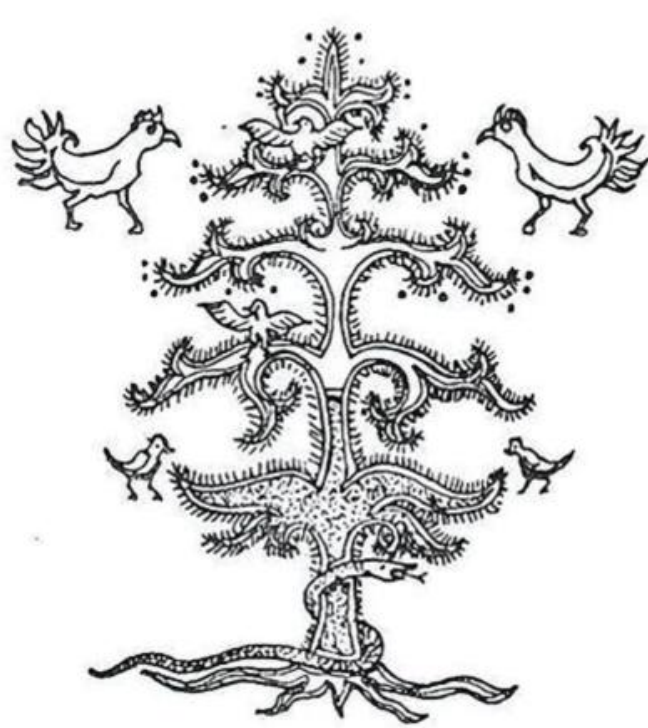

Gambar 10. Ukiran Gorga Hariara Sudung di Langit, Sumber: https:// togapardede.files.wordpress.com/

(diakses 18 Juni 2014)

Sedangkan pada ranting bawah terlukis gambar manuak-manuak imbulu buntal yang berwarna merah, membawa pada patuknya. Gorga Hariara Sudung di Langit bermakna sebagai manusia yang harus senantiasa mengingat penciptanya.

\section{Gorga Gaja Dompak}

Gorga Gaja Dompak memiliki bentuk seperti jenggar, hanya berbeda dalam posisi

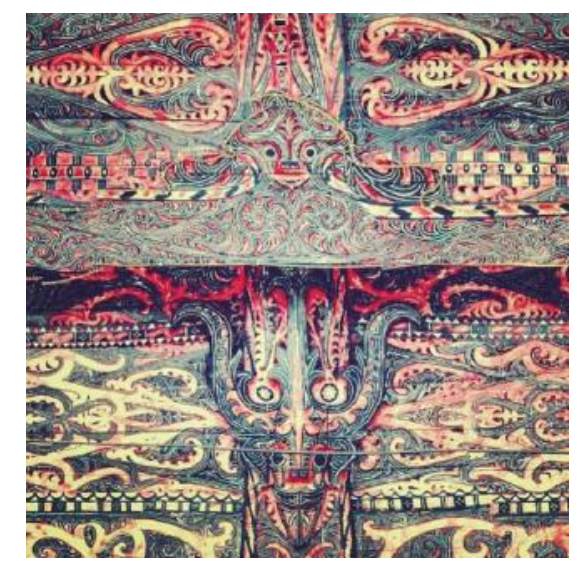

Gambar 11. Ukiran Gorga Gaja Dompak, Sumber: https://c1.static flickr.com/ (diakses 18 Juni 2014) 
pemakaiannya. Gaja Dompak diletakkan tergantung pada ujung dila paung. Gorga ini bermakna sebagai simbol kebenaran bagi orang Batak. Artinya manusia harus mengetahui hukum yang benar ialah hukum yang diturunkan oleh Tuhan Mulajadi Nabolon. Oleh karena itu, Gorga Gaja Dompak berfungsi sebagai penegak hukum kebenaran terhadap semua umat manusia (Sitanggang, 2008: 155).

\section{Gorga Dalihan na Toru}

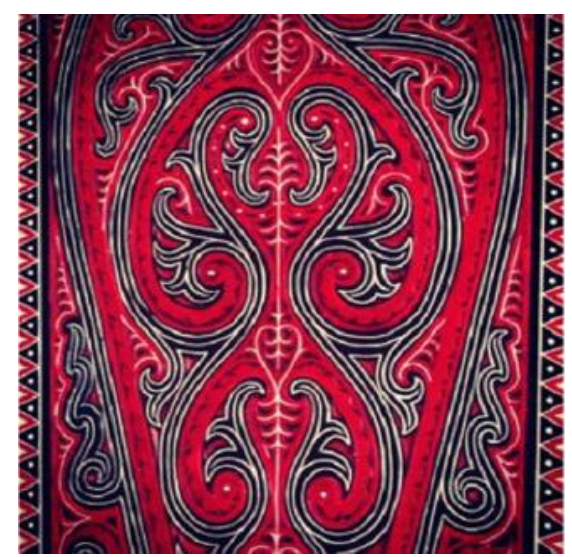

Gambar 12. Ukiran Dalihan na Tolu, Sumber: http://halakhitaon.files. wordpress.com/, (diakses 18 Juni 2014)

Gorga Dalihan na Toru merupakan gorga yang berbentuk jalinan sulur yang saling terikat. Hal ini melambangkan falsafah Dalihan na Toru yang merupakan falsafah hidup orang Batak dalam menjalin hubungan dengan sesama manusia (diakses melalui www.gobatak.com, tanggal 12 Juni 2014, jam 19.42 WIB).

\section{Gorga Simeol-Eol}

Gorga Simeol-Eol berasal dari kata Meolmeol, yang artinya melenggak-lenggok. Pada ukiran gorga ini bentuk garisnya melengkung meliuk keluar yang menunjukkan keindahan sehingga menimbulkan kesan gaya klasik. Gorga Simeol-Eol ber-

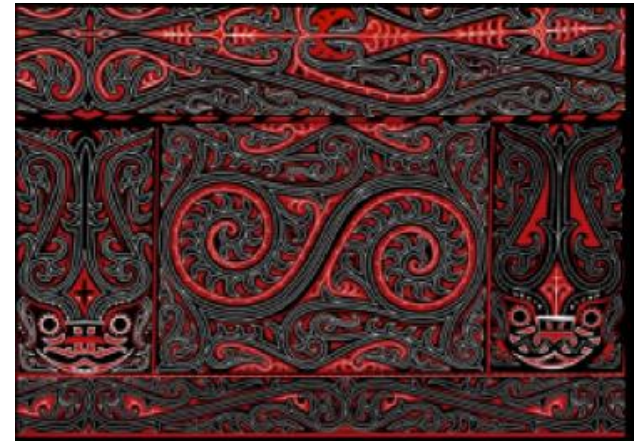

Gambar 13. Ukiran Gorga Simeol-Eol, Sumber: http://sarunaisumatera. wordpress.com/ (diakses 18 Juni 2014)

makna sebagai lambang kegembiraan dan berfungsi untuk menambah keindahan (Sitanggang, 2008: 146).

\section{Gorga Sitagang}

Gorga Sitagang berasal dari kata Tagan, yang artinya kotak kecil untuk menyimpan sirih, rokok, dan benda kecil lainnya. Pada Gorga Sitagang memiliki bentuk simetris, seperti tutup kotak dan kotak yang ditutup pada tagan tersebut. Gorga Sitagang memiliki makna kerendah hatian dalam menerima tamu.

\section{Gorga Sijonggi}

Gorga Sijonggi berasal dari kata jonggi, artinya lambang dari kejantanan, yang terkenal pada kelompok sapi. Sapi jantan yang memimpin rombongan dikatakan sebagai lombu jonggi. Makna pada Gorga Sijonggi ialah keperkasaan yang dihargai dan dihormati (pahlawan).

\section{Gorga Silintong}

Gorga Silintong memiliki bentuk seperti putaran air. Gorga Silintong dianggap sebagai gerakan pusaran air yang garisnya indah. Air silitong terdapat dalam guci yang disebut pagar, yaitu sejenis air yang mengandung kesaktian. Air sakti dianggap istimewa kejadiannya, oleh karenanya tidak 
semua rumah memilikinya. Gorga Silintong bermakna simbolik, dianggap memiliki kekuatan yang sakti, yang dapat melindungi manusia dari segala bala. Dan biasanya pemilik ukiran ini ialah raja-raja adat yang dianggap berilmu seperti datu atau guru dalam ilmu yang dianggap ajaib sehingga mampu melindungi masyarakat.

\section{Gorga Iran-iran}

Iran ialah sejenis penghias muka manusia supaya dapat terlihat menarik dan berwibawa. Oleh karenanya Gorga Iran-iran dimaknai sebagai lambang kecantikan.

\section{Gorga Hoda-hoda}

Gorga Hoda-hoda merupakan gambaran ilustrasi yang disebut diulang-ulang dengan gambar orang yang sedang mengendarai kuda (hoda). Gambar pada gorga ini menceritakan suasana pesta adat, yaitu pesta mangaliat horbo (pesta besar). Gorga Hoda-hoda bermakna sebagai kebesaran. Melalui gambar mangaliat horbo menandakan pemilik rumah berhak untuk melakukan pesta mangaliat horbo (pesta besar).

\section{Gorga Ulu Paung}

Gorga Ulu Paung berbentuk menyerupai gambaran setengah manusia dan setengah hewan. Ulu Paung bermakna sebagai simbol keperkasaan untuk melindungi manusia seisi rumah. Oleh karenanya gorga ulu paung dijadikan sebagai penjaga setan-setan dari luar kampung.

Berbagai macam bentuk gorga memiliki makna-makna kehidupan didalamnya. Ukiran gorga memberikan kemegahan pada setiap bangunan. Berbagai macam bentuk ukiran gorga menandakan adanya suatu makna simbol yang menunjukkan bahwa adanya nilai budaya yang masih bertahan didalam kebudayaan Batak.

\section{SIMPULAN}

Ukiran Gorga merupakan seni kebudayaan yang ada pada masyarakat Batak. Pada ukiran gorga terdapat bentuk yang bermacam-macam. Adapun jenis bentukbentuk ukiran gorga pada rumah adat batak ialah gorga sompi, gorga ipon-ipon, gorga desa na ualu (mata angin), gorga simataniari (matahari), gorga simarogung-ogung, gorga singa-singa, gorga jenggar dan jorngom, gorga boras pati (cecak), gorga adop-adop (susu), gorga gaja dompak, gorga dalihan na toru, gorga simeol-eol, gorga sitagang, gorga sijonggi, gorga silintong, gorga iran-iran, gorga hariara sudung di langit, gorga hoda-hoda, dan gorga ulu paung.

Berdasarkan bentuk-bentuk tersebut, ukiran gorga memiliki makna pada setiap bentuknya. Makna dalam ukiran gorga Batak menunjukkan bahwa adanya makna simbolis yang terdapat dalam setiap elemen di ukiran gorga. Sehingga hal ini menunjukkan bahwa adanya nilai-nilai budaya yang masih bertahan dalam kebudayaan masyarakat Batak. Melalui semiotik dapat memahami tanda yang muncul dalam ukiran gorga. Tanda terdiri dari dua konsep yaitu penanda dan petanda, dan keduanya tidak dapat dipisahkan. Penanda dan petanda membentuk tanda. Teori semiotika digunakan untuk mengetahui makna melalui relasi tanda-tanda yang ada dalam sebuah ukiran gorga.

\section{Daftar Pustaka}

Ani Soekowati

1993 Aart van Zoest Semiotika Tentang Tanda, Cara Kerja dan Apa Yang Kita Lakukan Dengannya. Jakarta: Yayasan Sumber Agung.

Berger, Arthur Asa

2010 Pengantar Semiotika Tanda-tanda dalam Kebudayaan Kontemporer. Yogyakarta: IKPI. 
Sitanggang, Jan Pieter.

2008 Raja Na Pogos. Yayasan LPB3 Indonesia.

\section{Sumber Lain}

Anneahira. Ukiran Batak: Simbolik dan Mengandung Unsur Magis.

http://www.anneahira.com/ukiranbatak.htm tanggal 16 Juni 2014,jam 15.48.

Erictoga Gultom, Rumah Gorga Batak.

http://erictogagultom.blogspot.com/2011/

12/jabu-batak.html.

http://2.bp.blogspot.com /gorga.jpg, tanggal 18 Juni 2014, jam 11.16.

http://www.gobatak.com/, tanggal 12 Juni 2014, jam 19.42.

https://togapardede.files. wordpress.com/ tanggal 18 Juni 2014, jam12.42

http://s1174.photobucket.com/ tanggal 18 Juni 2014, jam 11.34

https://c1.staticflickr.com/9/8163/ 7642763860_7241450350_z.jpg tanggal 18 Juni 2014, jam 12.15

Eriston Purba, Batak.

https://halakhitaon.wordpress.com/ tanggal 18 Juni 2014, jam 12.19
Harean Hutagalung, Horas.

http://hutagalunharean16.blogspot.com/ 2014/05/gorga-batak-seni-kas-orangbatak.html, tanggal 18 Juni 2014, jam 11.06.

Putri Vera Hutapea, Cicak, Simbol Unik Suku Batak untuk Bertahan Hidup.

http://travel.detik.com/read/2013/10/14/ 133500/2198788/1025/cicak-simbol-uniksuku-batak-untuk-bertahan-hidup tanggal 18 Juni 2014, jam 12.05.

Raymond Sitorus, Gorga Batak. http://raymondsitorus.files.wordpress. com/2011/10/gorga-batak.jpg, tanggal 18 Juni 2014 jam 11.27.

Rido Manik, Gorga Batak. http://akubatak.blogspot.com/2013/08/ gorga-batak.html tanggal 18 Juni 2014 jam 10.53 . 